\title{
Monastic Philosophy of the Origins of University Education
}

\author{
Charles Ogundu Nnaji \\ Department of Philosophy and Religions, University of Abuja, Abuja, Nigeria \\ Email: economos34@yahoo.com
}

Received 20 October 2014; accepted 24 March 2015; published 26 March 2015

Copyright (C) 2015 by author and Scientific Research Publishing Inc.

This work is licensed under the Creative Commons Attribution International License (CC BY). http://creativecommons.org/licenses/by/4.0/

c) (i) Open Access

\begin{abstract}
The study looks at how modern universities emerged from medieval Catholic monasteries, especially from theological philosophies, which prompted Catholic Friars to form guilds of children in monasteries for catechisms and teachings on doctrine (doctorate) from 1200 to 1225 CE. These guild centers in monasteries that soon graduated into teaching centers for the new knowledge (or science) transformed the monastery guilds into universities with Saint Thomas Aquinas as one of the earliest graduates of those universities around $1250 \mathrm{CE}$.
\end{abstract}

\section{Keywords}

Monastic, Philosophy, Origin, University, Education

\section{Introduction}

This introduction is not a linguistic analyse of the Latin and Greek word "Education", rather it gives us an idea of the origin of that word "Education". More often, we are told that the word "Education" is from the Latin "Educare” or "Educatio" (See Wilson, 1965 to find out sources of Latin words in English, since there are languages much older than Latin see also Palmer, 1987). Latin was in its rudimentary stages around 300 BC, and without alphabets or organized written forms; while Greek which gave Latin many words was in its own primary stages around 1000 BC (700 years older than Latin). Hebrew which gave Greek its alphabets developed around 1900 BC (900 years older than Greek) (Mansoor, 2004: p. 23). Hence, when you see a Latin word, look at its origin because Latin is not really ancient, rather it became prominent being the official and spiritual language of the Holy Roman Catholic Latin Empire (or the Latin Church) (Palmer, 1987). The Latin words "Educare” and "Universal” (now university) have origins which are traceable to ancient Greek: The Greek "Edoka” means "I gave” which in turn is also from Greek "Dotein or Didomi” (now deduction) which means "I give or I take from (Brown \& Comfort, 1990)". The Latin "Uni” has its link to the Greek "Uranos”, which means the heavens or 
wide expanse of space above (Metzger, 2001). Hence, there is hardly any Latin word which has no links in Greek. Greek words such as "Didache-Teaching", which gave us Didactic, means "teaching skills"; while from Greek "Pedagogu” we got "Pedagogy”, i.e. child education; "Paedo" is child (paediatrics) "gogu” means trainer, master or child leader (Aland \& Newman, 1983).

\section{Objective of the Study}

a) This study presents the origin of modern university education as a "Default", since modern universities started as learning guilds in Catholic Monasteries from 1200 CE for teaching Catholic moral doctrines (doctorate) and putting forward or laying down (i.e. "Theso" now Thesis-John 10: 17-18). Catholic moral principle rebellion in the Church. That monastic philosophy for moral education was pushed out by new knowledge called science which led to Protestantism.

b) From no (a) above, this study clearly reveals how Catholicism produced modern from Catholic monasteries used as pioneer universities through its monastic learning guilds and scholastics (and friars) who formed the first generation of academic staff from the Carmelites, Dominicans, Augustinians, then Jesuits etc.

\section{Literature Review}

Wilson (1965: p. 124) presented the Latin words "Universum” (whole world) "Universus" (entire or altogether) and "Universitas" (universe) all with roots to "Uni”, "Unio", e.g. "Unionis”, i.e. unity. While Brown and Comfort (1990) and Aland and Newman (1983), gave us the Greek word "Edokai” (I gave or to take) from "Didomi", or "Dedokai" (now deduction) related to the Latin "Educatio" (to bring up) as sources of the word "Education". "Educo" (lead or bring up) children which currently and technically means passing on information or knowledge for the sole purposes of skills acquisition and moral training to refine the human mentality and the human character (Oxford, 1995).

Brockman and Pescantini (1991), reviewed by Njure, (2004: pp. 86-88) stated that Catholic Friars from (1190 $\mathrm{CE}$ to $1215 \mathrm{CE}$ ) emerged as new teachers for the teaching (Didache) of sound doctrine after the crusades (against invading Islam). Modern universities developed from children's learning guilds formed in monasteries by Dominician, Franciscan, Augustinian and Carmelite Friars (p. 87).

The monastic-philosophy, reason, or wisdom for organizing those learning guilds in monasteries was to teach sound Christian doctrines (Doctrina-Doctorates-teachers of the Christian doctrine). The first modern monasterycollege (or guild) that became a university was in Italy around 1215 CE (p. 88) where students organized themselves around their friar teachers. The young students went to the monasteries to look for friars who can teach them sound Christian doctrines. There they arranged themselves into collegiums (college-from Greek—kaleos, i.e. called to learn, doctrine or calling). There in Italy the first modern universities developed from Catholic monasteries in Bologna and Padua, both universities which soon deviated from teaching the Christian doctrine to teaching and researching into new ideas in Medicine around 1215 CE. Catholic-England soon also produced Oxford and Cambridge Universities, while Catholic France produced universities at Paris and Toulouse. Another university came up from Salamanca in Catholic-Spain, and in Prussian and Bavarian Germany including in the United Netherlands before Southern Catholic Netherlands (now Belgium) broke away from the North (now Netherlands) which occurred during the Catholic-Protestant wars of 1529 to $1648 \mathrm{CE}$ etc. (Church Reformation NET, 2012).

Brockman and Pescantini (1991) and Njure (2014: p. 88) by 1215 CE the papacy promulgated operating laws for the New Universities totaling about twenty-five all over the Roman Catholic Europe. Latin, the language of Catholicism was the legal and only language of instruction or teaching for the universities and colleges; while children as young as twelve were admitted into the universities which produced great scholars like St. Thomas Aquines (1225-1274), Roger Bacon (1214-1293), and St. Albert (1173-1250) etc.

\section{Please Note}

However, the universities ended up producing Christian medieval philosophers who developed Physics, Genetics, Medicine and Experimental Science, these which completely derailed the moral and doctrinal philosophies or reasons for setting up the learning monastery guilds that produced the modern universities.

Unfortunately, as science pushed out moral and doctrinal teachings from the Catholic universities, socialism 
and positivism 400 years later from 1700 worsened the situation as science and the social sciences which were produced from Catholic-Monasteries by Catholic Friars, started abusing and condemning the theological arguments and brainstorming that produced them.

\section{Methodology}

Relevant literature has been consulted. Also included is a statistical table of Mission schools, colleges of theology and universities currently owned by Catholicism and Protestantism, especially with the question, "Why do churches set up educational institutions?”

\subsection{Justification for the Study}

a) Many wrong information on the origins of University Education are out there conflicting on many online websites. The interesting thing is that many of these online research papers have never really touched on the theological or religious origins of modern universities; yet and ironically, this untouched theological angle is the truth about the true origin of modern universities, which is Catholic and which is true (Brockman \& Pescantini, 1991, 2004: pp. 56-88).

b) Hence, the justification for this study lies in its attempt to correct wrong online information and other wrong research studies on the true origins of modern university education.

\subsection{Possible Problem of This Study}

It is possible some people will agree with this study, while some other antitheist people will disagree especially secularist and anti-God people who see nothing good coming out of religion, yet in their private closets, they constantly weep at the feet of a merciful God, but hypocritically and publicly they hate God and clamp down on anything religion, especially they constantly falsify, hide, deny, cover, eliminate and even destroy every and any information linking religion to our modern science, technology, social sciences and the humanities. To them, "Religion has no business with science and technology", yet take it or leave it, religion produced science and technology when Church Theologians, 9, i.e. scholastics of 1300 to 1700, were looking for physical proofs or natural laws to prove that God exist; which we now call Physics etc.

\subsection{Definition of Terms}

\section{Explanation of the Topic: Monastic Philosophy of the Monastic Origin of Modern University} Education

The monastic philosophy of early Monastic Education simply means that what eventually materialized from Catholic Monastic teachings of doctrine and morality, was not intended to be centers for learning science and technology, rather the teaching of the doctrina (doctrines) of Catholicism incorporated new discoveries from science which practically witnessed Catholic monks and churchmen as pioneers in discovering scientific laws: examples include; Father Mendelson on Genetics; Church scholastic/Philosopher Isaac Newton on gravity. St. Albert the Great (1770 CE - 1280 CE), one of the foundation layers of physics before Isaac Newton. Also, Roger Bacon a Franciscan of 1214 CE - 1292 CE including ,many friars and theologians like St. Thomas Aquinas (1225 $1274)$ and St. Bonaventure (1221 - 1274) whose philosophical-theologies helped to carve science out of theology and philosophy (Brockman \& Pescantini, 1991/2002: p. 88).

a) MONASTIC: Monastic is from Latin "Monasterium" Greek "Monas" which means "alone or only", hence, technically "monastic" means "leaving alone", isolated or separated from others (Aland \& Newman, 1983: p. 118). In current English, Monastery is a Roman Catholic Christian doctrine of separating priests into celibate and isolated life of constant prayers and spiritual ruminations (Hawkins, 1995).

b) PHILOSOPHY

i) For many years, people (or secularists) defined philosophy as love (philos) for wisdom (Sophia). However, in 2012, the true roots of philosophy were revealed as "Philos" (love) and snake or serpent (Ophis-Opheos) which means love of deceit (Nnaji, 2012). To further prove this, see Mathew 10:16.

"Jesus said:"

"Be as wise as serpents (Opheos)” Mtt 10:16. (Please read the original Greek language New Testament) 
The point is that the Greek words "Ophis” or "Sophis” means snake or serpent (Brown \& Comfort, 1990).

ii) Please note: Colossians 2:8 gave us the true meaning of philosophy, i.e. "Philos" (love) plus "Ophis” (deceit) "empty deceit or human reasoning".

iii) Skinner (2011) traced the wisdom religions of the ancient past to the snake (Ophis) as the symbol of wisdom, Metzger (2001) also cited the New Testament era Gnostics called “Ophites" as holding the "serpent” (Ophis) as the symbol of mysterious or spiritual wisdom, Colossians 2:8. See to it that no one takes you captive through empty or deceitful (Ophis-snake-deceiver) philosophy or false teachings (Aland \& Newman, 1983).

iv) Aland and Newman (1983: p. 124), defined "Philosophia" as false teaching.

c) ORIGIN: The word origin (or etymology) simply implies root, cradle, beginning or created (Greek-Genetesnow Genetics). From origin we derived "Original" "Originator" and "Originating" etc. all pointing to the source, root or starting point of something. (See Chambers, 1996)

d) MODERN: Wilson (1965) modern (p. 226) means "novum, or novelty"-recent or new things from Greek "Neo" (New). See Metzger 2001—see also Simpson and Weiner, 1989) etc.

e) UNIVERSITY: University from Latin "Unio" (single or only) and "Universitas", i.e. entire or altogether (Wilson, 1965: p. 124), Universitas, i.e. from Latin "Universum" which means "the whole world". Applied technically to Education, Universitas simply means bringing together different parts of human endeavors or knowledge.

f) EDUCATION: Please see introduction.

Palmer (1987) confirmed by Wilson (1965) in their Latin definitions of the word "Educatio" from Greek "Edoken-I gave-Brown and Comfort, 1990 etc.—state that "Education" means "to bring up, erect or build especially of character building, i.e. building a person's morality, this which was the monastic philosophy of setting up monastery learning guilds from $1200 \mathrm{CE}$ which matured into our modern universities. The point was that friars of the Dominicans, Augustinians, Carmelites etc. were trying to correct the moral decadence which the Holy Roman Catholic Empire had relapsed into, which eventually led to the rebellion against Catholic immoralities. That rebellion was called "Protestantism" or Church Reformation (Schaff, 1962).

However, the learning centers or guilds in those medieval monasteries ended up introducing new knowledge or learning called "science" different from moral studies which collapsed the moral aims of the monastic education guilds, thereby producing Church scholastics made up of medieval Christian philosophers, theologians and scientists (e.g. Thomas Aquinas) who produced our modern scientific (rather than theological) university education system. The idea of the "Universal" education was that moral training and science education can be combined which is the real meaning of "university". Eventually, science education overshadowed moral instructions. To this day from 800 years ago science consistently abuses moral studies.

\section{Data Analyses}

Why do religious bodies set up educational institutions: Is it for moral or science studies?

Please check Religious Schools Data Analysis (Table 1).

Please note that data presented clearly show that religious groups are not really set-up for mainly theological reasons, rather they obey government drive towards science education than religious studies.

\section{Limitations of the Study}

Relevant literature on research topics is often not easily available. Conducting fieldwork or empirical collection of data needs research assistants, transportation, covering of distances and payment of costs; while most online information or publications often do not present true or correct information, especially many of our internet or online research papers falsify theological origins of our modern civilization, with the intention of denying religious or theological origins of modern science, technology, social sciences and humanities.

\section{Research Conclusions and Contributions}

1) The research clearly presented how modern universities appeared from 1200/1215 CE from Catholic monasteries for the sole purpose of teaching sound Christian moral doctrines.

2) By 1300 to $1400 \mathrm{CE}$ the teaching of medicine, science and capitalist new ideas practically pushed Christian 
Table 1. Data analyses: Reasons for religious institutions (for you to understand this table, please read "Education" under definition of Terms above).

\begin{tabular}{|c|c|c|c|}
\hline & Religious Schools in Nigeria & For Science Education & For Moral Education \\
\hline 1 & $\begin{array}{c}\text { Catholic Mission Schools about } 6000 \text { in } \\
\text { Nigeria }\end{array}$ & $\begin{array}{l}\text { Respondents: say } 80 \% \text { for science and } \\
\text { philosophy }\end{array}$ & For only $15 \%$ moral studies \\
\hline 2 & Protestant Mission Schools over 7000 & Respondents: say $60 \%$ for science studies & For only $30 \%$ moral studies \\
\hline 3 & Pentecostal Mission Schools c. 10,000 & Respondents: say $60 \%$ for science studies & For only 35\% moral studies \\
\hline 4 & $\begin{array}{l}\text { Informal Islamic Quranic Schools } \\
\text { c. } 5000\end{array}$ & $\begin{array}{c}\text { Respondents: say } 10 \% \text { for science } \\
\text { education }\end{array}$ & For $70 \%$ doctrinal education \\
\hline 5 & $\begin{array}{l}\text { Informal Pseudo-Religio-Philosophical } \\
\text { Schools; e.g. Eckankar, Ogboni etc. } \\
\text { c. } 500 \text { in Nigeria }\end{array}$ & $\begin{array}{l}\text { Respondents: say } 70 \% \text { for mystical } \\
\text { and philosophical teachings }\end{array}$ & For $20 \%$ moral education \\
\hline 7 & $\begin{array}{c}\text { Informal African Traditional Religion } \\
\text { Schools over } 5000\end{array}$ & $\begin{array}{l}\text { Teachings on how to prepare } \\
\text { mystical medicinal herbs }\end{array}$ & $\begin{array}{l}\text { About } 10 \% \text { moral teachings: Since } \\
\text { most of those traditional medicinal } \\
\text { teachings are being used negatively. }\end{array}$ \\
\hline 8 & Catholic Universities in Nigeria, over 10 & 80\% Science Education & 15\% Moral Studies \\
\hline \multirow[t]{2}{*}{9} & Islamic Universities in Nigeria over 2 & $60 \%$ Science Education & 35\% Moral Studies \\
\hline & Religious Schools in Nigeria & For Science Education & For Moral Education \\
\hline 10 & Protestant Universities in Nigeria: over 8 & 70\% Science Education & 20\% Moral Studies \\
\hline 11 & $\begin{array}{l}\text { Pentecostal Universities in } \\
\text { Nigeria over } 10\end{array}$ & 70\% Science Education & 20\% Moral Training \\
\hline 12 & Government Universities c. 47 & For 98\% Science and Secular Education & 1\% Moral Education \\
\hline
\end{tabular}

Nnaji, C. O., 2012, Journal of Information and Statistics Theology.

Theology out of the New Catholic European Universities.

3) By 1700 to 1750 CE after the Protestant Catholic wars (Church Reformation NET, 2011) people like young Adam Smith from Scotland rather than study Theology at Oxford or Cambridge opted for Philosophy and Latin, in order to emulate skeptist—David Hume (See Adam Smith NET, 2012).

4) Medieval Christian philosophy revived Aristotelian classical Philosophy in that era of the Renaissance (1300). Philosophy was to later label religion as "useless" (See Augustus Comte).

5) Clearly, this study has established that Catholicism produced our modern universities; however, universities deviated into new ideas called "science" which eventually labeled Religion and Theology as "dangerous and outdated”.

\section{Research Suggestions}

1) This research effort suggests that scholars should go deep enough into their research topics, especially that Latin words are not really the bus stop of English words, this which means that (a) Latin derived many words from the Greek language New Testament when the New Testament was being translated from Greek to Latin between $399 \mathrm{CE}$ and $450 \mathrm{CE}$.

2) Latin also derived many Greek words between 29 BC and 350 CE when the Roman Empire was still adopting Greek because of how Alexander the Great (323 BC) popularized Hellenism and Greek all over the world (Mccain, 2005).

3) It is the suggestion of this study that research writers should not take online materials as fool proof, since many of those online write-ups are not correct, especially coming from secularist and anti-God European and other western scholars who primarily falsify related religious information, particularly to abuse or give Religion a bad name that Religion has no role in the emergence of modern universities, science and technology. Most of these falsifications and abuse of Religion are often done by philosophers, social scientists and Marxists etc. 


\section{References}

(1984). New International Version of the Holy Bible. Colorado Springs: IBS.

(1990). The New Revised Standard Version of the New Testament. Tyndale Illinois.

Aland, K., \& Newman, B. (1983). New Testament Greek and Lexicon. Stuttgart: WBS.

Brockman, N., \& Pescantini, W. (1991). A History of the Catholic Church (pp. 86-88). Nairobi: Paulines. (Reviewed by Njure (2004))

Brown, R. K., Comfort, P. W., \& Douglas, J. D. (1990). The New Greek-English Interlinear New Testament. Illinois: Tyndale.

Church Reformation NET (2012). Church Reformation NET-The Senseless Protestant-Catholic Wars, 1618-1648 NET 2011.

Hawkins, J. (1995). The Oxford Mini Reference Dictionary of English. London: Oxford.

Maier, P. L. (Translator and Editor, 1988). Josephus, The Essential Writings (Grand Rapids; Kregel). Also Maier P. L. (Translator and Editor) Eusebius the Church History.

Mansoor, M. (2004). Step by Step Biblical Hebrew. Illinois, Baker.

Nnaji, C. N. (2012). Origin and True Meaning of Philosophy. Abuja: Theometry.

Nnaji, C. O. (Ed.) Theology. Journal of Information and Statistics Theology (Enugu, Theometry).

Palmer, L. R. (1987). Latin Language. Oklahoma: Oklahoma University.

Simpson, E. S. C., \& Weiner, J. A. (Eds.) (1989). The Oxford Encyclopaedic English Dictionary. Oxford: Clarendon Press.

Skinner, A. (2011). Symbols and Serpents. In C. O. Nnaji (Ed.), Origin and True Meaning of Philosophy. Abuja: Theometry.

Smith, A. (2012). NET.

Wilson, A. (1965). The EUP Latin-English Dictionary (pp. 40, 124). London: EUP. 